УДК 341.171

ІМПЛЕМЕНТАЦІЯ УГОДИ ПРО АСОЦАЦІЮ МІЖ УКРАЇНОЮ
ТА ЄС - ОДИН ІЗ ГОЛОВНИХ ПРІОРИТЕТІВ У ПДГОТОВЦ
ЮРИСТІВ-МІЖНАРОДНИКІВ У ЛЬВІВСЬКОМУ УНІВЕРСИТЕТІ

\title{
Михайло Микієвич
}

\author{
Львівський наиіональний університет імені Івана Франка, \\ вул. Університетська, 1, м. Львів, Україна, 79000, тел. (032)231-41-99, \\ e-mail:mmmedulaw@gmail.com
}

3 набуттям чинності Угоди про асоціацію між Україною та ЄС розпочався новий етап реалізації євроінтеграційної стратегії нашої держави. Тривалий процес підготовки Угоди, трагічні сторінки, пов'язані із іiі підписанням, та умови військового конфлікту на сході України, в яких, власне, і відбулося набуття нею чинності, вимагають від суспільства особливих підходів до оцінки документа як політико-правового інструменту досягнення зовнішньополітичних цілей нашої держави з метою приведення внутрішніх економічних, політичних та соціальних критеріїв до європейських та світових стандартів. Власне, з метою підготовки фахових юристів-міжнародників для вирішення важливих завдань у сфері європейської інтеграції України створена 2003 р. однією 3 перших у державі кафедра європейського права. Кафедра сьогодні - один із провідних центрів дослідження та викладання права Європейського Союзу, що є, передусім, актуальним для сфери забезпечення європейської інтеграції України.

Ключові слова: Угода про асоціацію; Свропейський Союз; право ЄС; кафедра європейського права; зона вільної торгівлі.

У зв'язку з набуттям чинності 1 вересня 2017 р. Угоди про асоціацію між Україною та ЄС розпочався новий етап реалізації євроінтеграційної стратегії нашої держави. Тривалий процес підготовки Угоди, трагічні сторінки, пов'язані iз iï підписанням, та умови військового конфлікту на сході України, в яких, власне, і відбулося набуття нею чинності, вимагають від суспільства особливих підходів до оцінки документа як політико-правового інструменту досягнення зовнішньополітичних цілей нашої держави 3 метою приведення внутрішніх економічних, політичних та соціальних критеріїв до європейських та світових стандартів.

Власне, європейський вибір був зроблений Україною одразу 3 проголошенням державної незалежності. Національна самоідентифікація як європейської держави була задекларована ще 5 грудня 1991 р. у «Зверненні до парламентів і народів світу» у зв'язку з підтвердженням на референдумі Акту проголошення незалежності України [1]. Законодавче закріплення європейська мета отримала у схвалених 2 липня 1993 р. Верховною Радою основних напрямах зовнішньої політики України [2], в яких зазначено, що укладання 3 Європейськими Співтовариствами Угоди про партнерство і співробітництво

() Микієвич Михайло, 2017 
(УПС) стане першим етапом просування України до асоційованого, а згодом до повного членства у цій організації. Одразу наголосимо, що у цьому випадку й часто у засобах масової інформації термін «асоційоване членство в $\epsilon С$ » вживають помилково, оскільки стосовно відносин із третіми країнами (не членами організаціі) такої форми членства установчі договори Європейського Союзу не передбачають, а мова йде про встановлення відносин асоціації як особливої форми поглибленого співробітництва з Європейським Союзом.

Тема європейської інтеграції перебуває у центрі уваги вітчизняних науковців, чиї ідеї щодо місця і ролі України в сучасній Європі свого часу склали основу Стратегії інтеграції до Європейського Союзу 1998 р. Здійснений українськими вченими аналіз євроінтеграційних процесів дав змогу визначити практичні кроки зі створення передумов набуття членства в СС, що викладено в Посланні Президента України до Верховної Ради України «Європейський вибір. Концептуальні засади стратегії економічного та соціального розвитку України на 2002-2011 роки».

Своєю чергою, вже у цьогорічному Посланні Президента України до Верховної Ради України заплановано такі кроки та ініціативи нашої держави в процесі та після виконання у повному обсязі Угоди про асоціацію як асоціація із Шенгенською зоною, приєднання до Митного Союзу СС, Енергетичного Союзу ЄС, вступ до Спільного авіаційного простору та Спільного цифрового ринку. При цьому, як зазначено в документі, реалізація цих ініціатив фактично перетворить східні кордони України на східні кордони Євросоюзу ще до того, як ми де-юре приєднаємося до Союзу [1].

Набуття чинності Угоди про асоціацію між Україною та СС знаменує собою початок нового етапу взаємин України і наднаціонального інтеграційного утворення. Угода про асоціацію як безумовний пріоритет євроінтеграційної політики нашої держави $є$ орієнтиром у відносинах Україна-СС. У цьому контексті значимо, що асоційоване партнерство виходить далеко за межі простого регулювання торговельних відносин і стосується тісної економічної співпраці та широкомасштабної фінансової допомоги країні, 3 якою Європейський Союз уклав таку угоду відповідно до ст. 217 Договору про функціонування ЄС. Встановлення преференційних відносин і відповідна гармонізація законодавства асоційованих держав із правом Євросоюзу $\epsilon$ центральним елементом асоціації, хоча й сама Угода про асоціацію закладає інституційні засади співпраці фактично в усіх сферах взаємного інтересу. Ця угода покликана відіграти роль каталізатора внутрішніх реформ, успішна реалізація яких наблизить вступ України до ЄС. Це вимагатиме від української сторони активної позиції задля того, аби використати переваги, що надаватиме Угода.

Отже, нині Україна стоїть на рубежі, перетин якого означає перехід до нової якості відносин з $\mathrm{CC}$ - перехід від партнерства до асоціації. Угода про асоціацію з СС включно 3 поглибленою та всеосяжною зоною вільної торгівлі (ЗВТ) є документом стратегічного значення для розвитку України. Угода закладає нову основу для подальшого розвитку відносин між Україною та ЄС на принципах 
політичної асоціації та економічної інтеграції, яка підкріплюватиметься потужною інституційною базою і відповідатиме європейським очікуванням українців. Хоча, як слушно зазначає О. Стрельцова, «договірна практика $\mathrm{CC}$ свідчить, що між укладанням із третьою країною угоди про асоціацію та отриманням такою країною статусу кандидата у повноправні члени цього міждержавного об'єднання немає прямого правового зв'язку. Тобто асоціація може бути як сходинкою до членства в СС, так і його альтернативою» [3]. Проте послідовна й ефективна імплементація ії механізмів має створити міцний базис подальшого сталого політичного та економічного розвитку нашої держави, основу стратегіï реформування усіх ключових сфер i впровадження європейських стандартів з метою підвищення якості життя населення України, захисту фундаментальних прав особи. В основу політичної асоціації закладено зближення позицій України та СС з усіх питань міжнародного порядку денного, забезпечення безпосередньої участі України в політиках, агенціях та програмах ЄC, спільність дій 3 метою забезпечення інтересів національної безпеки Української Держави. Отже, політична асоціація України 3 Європейським Союзом спрямована на посилення європейських позицій України і на виконання пріоритетних стратегічних завдань зовнішньої та внутрішньої політики України. 3 огляду на це, особливої важливості набуває питання вибору інструментів практичної реалізації Угоди про асоціацію, або змістовного наповнення відносин, у тім числі й у рамках спільних органів, які передбачені цією Угодою. Наділення органів асоціації компетенцією приймати обов'язкові для сторін рішення підвищить ефективність їхньої діяльності в контексті асоціативних відносин. Це сприятиме вирішенню двох принципово важливих питань розширеної взаємодії між Україною та ЄС: $з$ одного боку, Україна отримає можливість брати участь у прийнятті рішень в євроінтеграційній спільноті у тих сферах, які становлять для нас безпосередній інтерес; 3 іншого боку посилиться рівень залучення Свросоюзу до здійснення перетворень в Україні.

Формула економічної інтеграції передбачає створення Зони вільної торгівлі між Україною та ЄС на основі чотирьох свобод (вільного руху товарів, капіталів, послуг і працівників), спрямованої на поступову інтеграцію України до внутрішнього ринку Євросоюзу. У майбутньому Угода про асоціацію та і11 торговельна частина, які передбачають широкомасштабну адаптацію законодавства України до законодавства СС, мають стати запорукою не лише для подальшого відкриття ринків, й для утвердження в Україні стабільного та привабливого бізнес-середовища.

Серед актуальних питань, які є спільними для інтересів нашої держави та $€ \mathrm{C}$, перше місце за важливістю посідає енергетична безпека, роль якої останнім часом суттєво зросла. У час, коли енергетичні ресурси стали одним 3 найефективніших методів просування геополітичних інтересів окремих країн, питання стабільності їхніх поставок займає перше місце у порядку денному багатьох країн Європи. Сьогодні Україна, як головний транзитер російського газу до країн $€ C$, зацікавлена у підтримці своєї репутації як надійного постачальника-транзитера $\mathrm{CC}$ у цій царині. Приєднання України до 
Михайло Микієвич

ISSN 2078-4333. Вісник Львівського університету. Серія міжнародні відносини. 2017. Випуск 42

Європейського Енергетичного співтовариства, що відбулося 24 вересня 2010 року, вимагає від українського уряду комплексного реформування енергетичного сектору, що відкриває можливості для створення в Україні сучасної моделі енергетичного ринку, модернізації існуючих газотранспортних та електричних мереж, а також для ефективнішого використання наявного експортного та транзитного потенціалу України. Крім того, входження України до внутрішнього енергетичного ринку Євросоюзу $\epsilon$ фактичним початком реалізації концепції секторальної інтеграції України до СС, закладеної в Угоді про асоціацію. Важливе значення у відносинах СС та України має безпековий вимір співробітництва. Сенс входження України до колективних структур безпеки у Європейському регіоні полягає в тому, щоб бути активним учасником європейської безпеки та мати реальні безпекові гарантії. Україні важливо реагувати на ерозію міжнародно-правових механізмів гарантування безпеки та брак надійних гарантій міжнародної безпеки нашої держави, що ставить іï у ситуацію вакууму безпеки [4].

Розглядаючи пріоритетні напрями доктрини міжнародного права України стосовно міждержавних союзів, додамо, що євроінтеграційна політика - чи не єдиний напрям зовнішньої політики України, що має ознаки сталості й неперервності. Без перебільшення можна стверджувати, що становлення сучасної України упродовж останніх 20-ти років відбувалося під помітним впливом ідеї європейської інтеграції. Український шлях до Європи - складний неординарний, отож, здебільшого, не витримує порівнянь та аналогій, чим він цінний [5].

Євроінтеграційний процес передбачає здійснення глибоких перетворень в Українській Державі, утвердження в ній демократії та верховенства права, модернізацію політичної системи задля захисту прав людини, формування цілісної демократичної ідентичності українського суспільства, поширення сучасних технологій політичного та економічного менеджменту, закріплення України як конкурентоспроможного гравця на світових ринках. Сила Європейського Союзу полягає у привабливості та зрозумілості його спільних цінностей та ідей. Партнерство між Україною та ЄС, як відомо, повинно грунтуватися на спільних цінностях та інтересах, чинниках підтримки миру, стабільності й процвітання в Європі. Оптимальний шлях до безпечного світу пролягає через зміцнення довіри на основі таких спільних цінностей. Повноцінна інтеграція України в європейський політичний, правовий, економічний і гуманітарний простір - це реалізація національних інтересів. Отож міжнародно-правова наукова доктрина і прийняті на іiі базі документи чітко декларують, що європейська інтеграція $\epsilon$ головним пріоритетом української зовнішньої політики.

Власне, з метою підготовки фахових юристів-міжнародників для вирішення важливих завдань у сфері європейської інтеграції України створена 2003 р. однією 3 перших у державі кафедра європейського права, яку з моменту заснування очолює проф. М. Микієвич. Висококваліфікований колектив кафедри, на якій працюють сім кандидатів юридичних наук, доцентів та один 
доктор юридичних наук, професор, у рамках спеціальності «міжнародне право», забезпечує спеціалізації «Право ЄС» та «Міжнародна адвокатура», які традиційно користуються великою популярністю серед студентів.

Кафедра на сьогодні стала одним із провідних центрів дослідження та викладання права Свропейського Союзу, що є передусім актуальним для сфери забезпечення європейської інтеграції України. Кафедрою підготовлено кілька перекладів у зарубіжних університетах, зокрема, Р. Штрайнц «Свропейське право» (Львів, 2009); М. Гердеген «Свропейське право» (Київ, 2008). Спільно 3 кафедрою міжнародного права започатковано унікальну англомовну магістерську програму з Вільнюським університетом (Литва) «Міжнародне та європейське право», після закінчення якої студенти отримають два дипломи обох університетів.

Наукові дослідження кафедри європейського права зосереджені на найактуальніших проблемах імплементації Угоди про асоціацію, зокрема, у сфері регулювання торгівлі з СС, соціальних відносин, зовнішніх зносин СС, міграційної політики Європейського Союзу, сфери безпеки, та інституційних механізмах діяльності ЄС. За цими науковими напрямами викладачами кафедри успішно захищені дисертаційні дослідження ${ }^{1}$.

Отже, накопичений за 25 років функціонування факультету міжнародних відносин Львівського національного університету імені Івана Франка значний науковий i викладацький досвід у сфері підготовки фахівців 3 права Європейського Союзу дає підставу стверджувати, що існує достатній потенціал для підготовки відповідних фахівців-юристів для всебічної імплементації Угоди про асоціацію України з СС, що сприятиме у подальшому досягненню кінцевої мети нашої євроінтеграційної стратегії - повноправного членства в СС з метою забезпечення європейських стандартів життя для наших громадян та захисту їхніх прав і основних свобод.

\section{СПИСОК ВИКОРИСТАНОЇ ЛІТЕРАТУРИ}

1. Право України. - 1992. - № 1. - С. 5.

2. Постанова Верховної Ради України Про основні напрямки зовнішньої політики України: № 3360-ХІІ від 2 липня 1993 року // Відомості Верховної Ради України. - 1993. - № 37. - Ст. 379.

3. Стрельияова O. Угода про асоціацію між Україною та Європейським Союзом: передумови, проблеми і перспективи // Право України. - 2012. - С. 92.

4. Ризики європейського інтеграційного проекту: виклики та можливості для України / І. В. Клименко, І. В. Ус. - Київ : НІСД,2012. - 88 с.

5. Копійка B. B. Євроінтеграція як стратегія розвитку України / В. В. Копійка // Незалежність України в глобалізованому світі: вектори XXI століття : міжнар. наук. конф. до

${ }^{1}$ Головко-Гавришева О. І. «Функції та компетенція Європейського Союзу у сфері соціальної політики»; Мозіль 3. М. «Міжнародно-правове регулювання торгівлі в рамках Європейського Союзу»; Яворська I. М. «Роль Суду СС у розвитку права Свропейського Союзу»; Брацук I. 3. «Імплементація права Європейського Союзу в національних правопорядках держав-членів»; Іваночко І.Б. «Міжнародно-правові стандарти статусу суддів»; Федунь М. В. «Правове регулювання поводження 3 відходами в рамках Європейського Союзу». 
20-річчя незалежності України (22 серпня 2011 p; Київ); упоряд.: Я. А. Жаліло, С. О. Янішевський. - Київ : Нац. ін-т стратегічних досліджень, 2011. - С. 166.

6. Головко О. I. Функції та компетенція органів Свропейського Союзу у сфері соціальної політики: Автореф. дис. канд. юрид. наук: 12.00.11 / О. І. Головко ; НАН України. Ін-т держави права ім. В. М. Корецького. - Київ, 2003.

7. Мозіль 3. М. Правове регулювання міжнародної торгівлі в рамках Європейського Союзу : дис. канд. юрид. наук: 12.00.11 / Київський національний ун-т ім. Тараса Шевченка. - Київ, 2004.

8. Яворська I. M. Роль Суду СС у розвитку права Європейського Союзу : Дис. канд. юрид. наук: 12.00.11. - Київ, 2011.

9. Брацук I. 3. Імплементація права Свропейського Союзу в національних правопорядках держав-членів : дис. канд. юрид. наук: 12.00.11. - Харків, 2011.

10. Іваночко I. Б. Міжнародно-правові стандарти статусу суддів : автореф. дис. канд. юрид. наук : 12.00.11. - Харків, 2016.

11. Федунь М. В. Правове регулювання поводження з відходами в рамках Європейського Союзу : дис. канд. юрид. наук : 12.00.11 / НАН України, Ін-т держави і права ім. В. М. Корецького. - Київ, 2016.

\title{
IMPLEMENTATION OF THE ASSOCIATION AGREEMENT BETWEEN THE EUROPEAN UNION AND UKRAINE AS ONE OF THE MAIN PRIORITIES IN TRAINING INTERNATIONAL LAWYERS IN LVIV UNIVERSITY
}

\author{
Mykhailo Mykievych \\ Ivan Franko National University of Lviv, \\ 1, Universitetska Str., Lviv, Ukraine, 79000, tel. (032)231-41-99, \\ e-mail:mmmedulaw@gmail.com
}

A new stage of implementation of the European integration strategy of Ukraine has begun with coming into force the Association Agreement between the EU and Ukraine. The long process Agreement's preparation, the tragic pages related to its signing, and the conditions of the military conflict in the eastern Ukraine in which it came into force, require from society specific approaches to the assessment of the document as a political and legal instrument for the achievement of foreign policy goals of our state. It is required in order to bring internal economic, political and social criteria to European and world standards. Actually, in order to prepare professional international lawyers for solving important tasks in the field of European integration of Ukraine, the Department of European Law was established in 2003 as one of the first in the state. Today the Department has become one of the leading research and teaching institutions of the European Union, which is primarily relevant to the sphere of ensuring European integration of Ukraine. Scientific researches of the Department of European Law are focused on the most significant problems of implementation of the Association Agreement. In particular, they are related to the field of trade regulation with the EU, social relations, external relations, European Union migration policy, security sphere and institutional mechanisms of the European Union.

Key words: Association Agreement; European Union; law of European Union; Department of European Law; Free Trade Area. 